\title{
Contribution of captured retroviral envelope genes, the "synctins" to the formation of the mouse placenta
}

\author{
Anne Dupressoir ${ }^{1 *}$, Cécile Vernochet ${ }^{1}$, Francis Harper ${ }^{1}$, Gérard Pierron ${ }^{1}$, Justine Guégan², Philippe Dessen ${ }^{2}$, \\ Thierry Heidmann ${ }^{1}$
}

From Frontiers of Retrovirology 2011

Amsterdam, The Netherlands. 3-5 October 2011

\section{Background}

In most mammalian species, a key process of placentation is the fusion of trophoblast cells into a multinucleated syncytiotrophoblast layer at the fetomaternal interface. Envelope proteins of retroviral origin, the syncytins, specifically expressed in the placenta and with in vitro cell-cell fusogenic activity, have been suspected to be involved in this process [1-5]. In mice, inactivation of syncytin- $A$ resulted in impaired formation of the syncytiotrophoblast layer I (facing the maternal blood lacuna) and in embryonic death [6], demonstrating that it is required for placenta development. Here, the effect of the inactivation of the second murine syncytin gene, syncytin- $B$, is described.

\section{Materials and methods}

We generated syncytin- $B$ mutant mice, and embryos homozygous mutant for syncytin- $B$ or for both syncytin$A$ and $-B$ were obtained at different gestational stages, through time mating intercrosses. The placentae of syncytin- $B$ null embryos were examined using histological analyses and refined electron microscopy analyses of the fetomaternal interface. Genes whose expression is modified in null placenta were identified using microarrays analyses and their expression was localized by immunohistochemistry.

\section{Results}

Syncytin-B null placenta disclose defects in formation of the syncytiotrophoblast layer II (facing the fetal blood vessels), with enlarged maternal lacuna disrupting the placenta architecture. At variance with the syncytin- $A$ phenotype, syncytin- $B$ null embryos are viable, although they still display late-onset embryonic growth retardation and a significant perinatal death rate. Interestingly, double SynA/SynB KO embryos die earlier than do embryos deficient for syncytin- $A$ alone, suggesting cooperative interactions. Finally, an induction of connexin-30 expression was observed in the syncytin- $B$ null placenta, with the protein being detected at the fetomaternal interface, suggesting a compensatory process whereby impaired syncytialization is counteracted by a gap junction mediated, cell-cell communication.

\section{Conclusions}

These findings demonstrate that syncytin- $B$ is essential for syncytiotrophoblast formation and placenta integrity. Altogether, our data demonstrate that the two murine syncytins contribute independently to the formation of the two syncytial layers. Placenta formation is therefore a complex process that has taken advantage of independent and stochastic "captures" of retroviral sequences in the course of evolution to generate "appropriate" structures and functions. Some of them are absolutely required for pregnancy, whereas the other could still be amenable to compensatory processes.

\section{Author details \\ 'CNRS UMR 8122, Institut Gustave Roussy, Villejuif 94805, France and Université París-Sud, 91405 Orsay, France. ²Unité de Génomigue Fonctionnelle, Institut Gustave Roussy, Villejuif 94805, France.}

Published: 3 October 2011 


\section{References}

1. Mi S, et al: Syncytin is a captive retroviral envelope protein involved in human placental morphogenesis. Nature 2000, 17:785-789.

2. Blond $\mathrm{J}$, et al: An envelope glycoprotein of the human endogenous retrovirus HERV-W is expressed in the human placenta and fuses cells expressing the type D mammalian retrovirus receptor. J Virol 2000, 74:3321-3329.

3. Blaise $S$, et al: Functional characterization of two newly identified Human Endogenous Retrovirus coding envelope genes. Retrovirology 2005, 2:19.

4. Dupressoir A, et al: Syncytin-A and syncytin-B, two fusogenic placentaspecific murine envelope genes of retroviral origin conserved in Muridae. PNAS 2005, 102:725-730

5. Heidmann $\mathrm{O}$, et al: Identification of an endogenous retroviral envelope gene with fusogenic activity and placenta-specific expression in the rabbit: a new "syncytin" in a third order of mammals. Retrovirology 2009, 27:107.

6. Dupressoir A, et al: Syncytin-A knockout mice demonstrate the critical role in placentation of a fusogenic, endogenous retrovirus-derived, envelope gene. PNAS 2009, 106:12127-12132.

doi:10.1186/1742-4690-8-S2-O24

Cite this article as: Dupressoir et al: Contribution of captured retroviral envelope genes, the "synctins" to the formation of the mouse placenta. Retrovirology 2011 8(Suppl 2):O24.

\section{Submit your next manuscript to BioMed Central} and take full advantage of:

- Convenient online submission

- Thorough peer review

- No space constraints or color figure charges

- Immediate publication on acceptance

- Inclusion in PubMed, CAS, Scopus and Google Scholar

- Research which is freely available for redistribution

Submit your manuscript at www.biomedcentral.com/submit 